DOI:10.15740/HAS/IJAS/12.1/143-145

\title{
Effect of different weed control methods on summer gujari rice
}

\author{
R.R. SHEWALE \\ Department of Agronomy, Anand Agricultural University, ANAND (GUJARAT) INDIA
}

\begin{abstract}
The experiment was conducted during summer season of the year 2009-10 at Regional Research Station, Anand Agricultural University, Anand to assess the response of rice to establishment techniques and weed control methods. Results revealed that transplanting 10-12 days old seedling with spacing of $25 \times 25 \mathrm{~cm}, 1$ plant hill ${ }^{-1}$ (System of Rice Intensification (SRI)) + 100:25:00 kg NPK, $25 \mathrm{~kg} \mathrm{ZnSO}_{4}$ ha $^{-1}, 25$ per cent $\mathrm{N}$ from FYM recorded best weed control than others. Pyrazosulfuron and use of rotary weeder also control the weeds. However,the hand weeding were efficient as compare to other.
\end{abstract}

Key Words : Weed control methods, Rice

View Point Article : Shewale, R.R. (2016). Effect of different weed control methods on summer gujari rice. Internat. J. agric. Sci., 12 (1) : 143-145.

Article History : Received : 15.12.2015; Accepted : 28.12.2015 